\title{
Mounier-Kuhn syndrome
}

\author{
Aswin Chandran 다, ${ }^{1}$ Prem Sagar (1) , ${ }^{1}$ Ashu Seith Bhalla, ${ }^{2}$ Rajeev Kumar ${ }^{1}$
}

${ }^{1}$ Otorhinolaryngology \& Head Neck Surgery, All India Institute of Medical Sciences, New Delhi, India

${ }^{2}$ Radiodiagnosis, All India Institute of Medical Sciences, New Delhi, India

\section{Correspondence to}

Dr Prem Sagar;

sagardrprem@gmail.com

Accepted 27 December 2020

\section{DESCRIPTION}

A 41-year-old previously healthy man presented to otolaryngology outpatient clinic with recurrent episodes of throat discomfort for last 6 months. There was no associated history of voice change, dysphagia, shortness of breath or cough. He denied any history of chronic productive cough, fever, wheeze, chest pain, weight loss, or previous lower respiratory tract infection. The patient was a nonsmoker without any occupational exposure to pollutants or allergens. The general examination was unremarkable, and clinical evaluation of oral cavity, larynx and neck was unremarkable. Routine haematological tests were unremarkable. Contrastenhanced CT of the neck was considered which was unremarkable except a dilated trachea and tracheal diverticuli. Further high-resolution CT of the chest revealed tracheomegaly, bilateral bronchomegaly with multiple diverticula along the right posterolateral aspect of trachea. The largest tracheal diameter was $32 \mathrm{~mm}$ at the level of thoracic vertebrae D1D2 (figure 1) and bilateral main bronchi measured $20 \mathrm{~mm}$ in diameter. Fibre-optic tracheobronchoscopy showed tracheal dilation and multiple diverticula in the right posterolateral region of trachea until carina and enlargement of both main bronchi (video 1). The mucosa of diverticulum appeared normal without retained secretion or blood. A clinicoradiological diagnosis of tracheobronchomegaly or Mounier-Kuhn syndrome was made, and the patient was kept on a close surveillance after explaining him the nature of the disease and the implications. With a course of proton-pump inhibitors, his symptoms settled and at 1-year follow-up, the patient remained symptom free.

Mounier-Kuhn syndrome or congenital tracheobronchomegaly is characterised by gross dilation of the trachea and bronchi which is a rare pathology due to atrophy or absence of smooth muscle cells and elastin fibres of the tracheobronchial tree. ${ }^{1}$ It may be associated with other congenital connective tissue disorders such as Ehlers-Danlos syndrome, cutis laxa and Marfan syndrome. However, pulmonary fibrosis due to interstitial pneumonia, sarcoidosis or cystic fibrosis can also lead to tracheobronchomegaly secondary to tracheal traction and subsequent dilatation. ${ }^{2}$ It manifests as dilation of central airway, tracheal and bronchial diverticulosis, reduced mucociliary clearance and stasis of secretion predisposing to

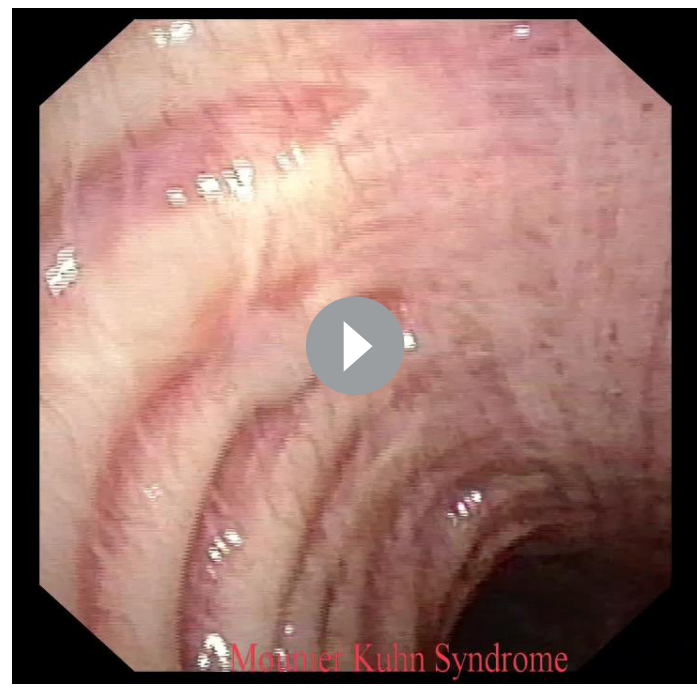

Video 1 The flexible tracheobronchoscopy revealing Mounier-Kuhn syndrome with dilated trachea and bilateral main bronchi with tracheal diverticulosis along the right posterolateral wall of trachea along with flexible tracheobronchoscopy of the trachea and main bronchi of a healthy adult

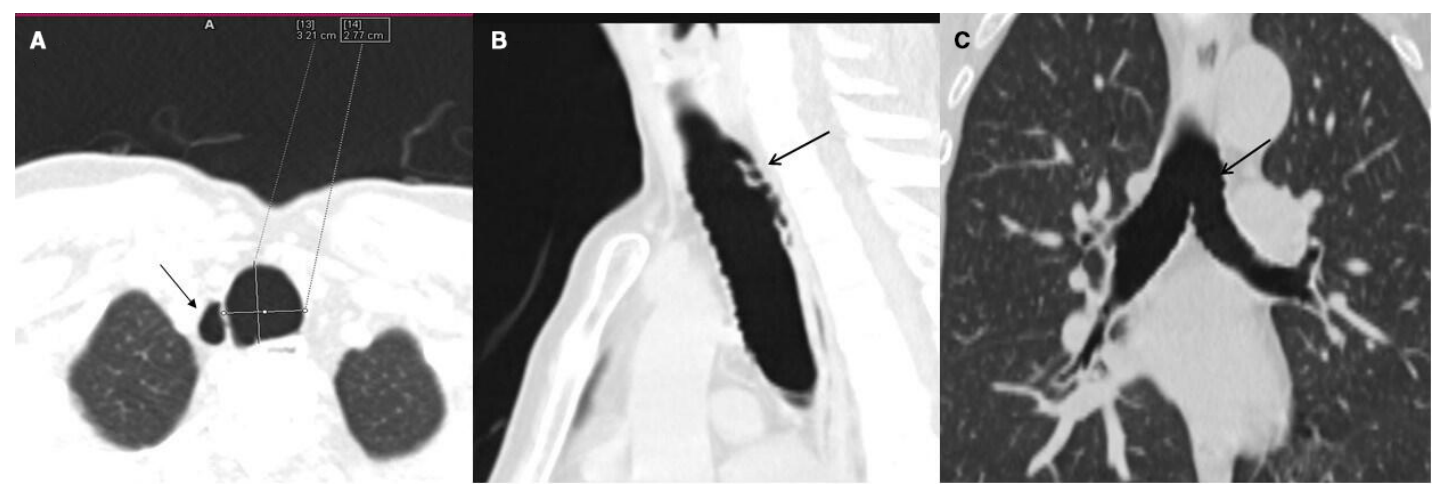

Figure 1 High-resolution CT (axial view) showing dilated trachea (transverse diameter of $3.21 \mathrm{~cm}$ at the level of D1D2) with right posterolateral tracheal diverticula ( $A$, black arrow), multiplanar reconstruction sagittal and coronal view $(B, C)$ showing multiple small diverticula (black arrows) along the posterior tracheal and bronchial wall with scalloped appearance. 
recurrent lower respiratory tract infections. The clinical presentation varies widely, from asymptomatic disease with preserved lung functions to recurrent chest infections, wheezing and exertional dyspnoea. Severe conditions may be complicated by

\section{Patient's perspective}

I experienced repeated throat problem for past six months for which I consulted ENT doctors. When my doctors did not find any problem in my throat on initial examination, they advised for a CT scan. After some more tests, I was told that I have condition where my windpipe is wider than normal along with some outpouchings from it. The doctors have assured me regarding the asymptomatic nature of my disease and have advised me to avoid of exposure to air pollutants and never to smoke (actively and passively). They also have asked me to seek medical care in case of breathing difficulty, blood in sputum, and recurrent cough with chest discomfort. My throat problems have resolved with treatment for acid reflux disease. Thankfully due to my throat complaints and my doctors' efforts I am aware of my uncommon disease, the symptoms it may cause as well as the preventive measures which I can follow to avoid symptoms.

\section{Learning points}

- Mounier-Kuhn syndrome is an uncommon condition but should be considered as a differential diagnosis in patients presenting with recurrent lower respiratory tract infections and chronic cough with expectoration though asymptomatic cases might not be as rare.

- CT of the chest with three-dimensional reconstruction is the gold standard for diagnosis which is supplemented by flexible tracheobronchoscopy.

- Pulmonary rehabilitation to improve mucociliary clearance and antibiotics during the infectious exacerbations are the primary modalities of treatment. bronchiectasis, pneumothorax, emphysema, pulmonary fibrosis and even respiratory failure. ${ }^{3}$ Though a plain chest radiograph may point towards dilated trachea, a CT of the chest is often required for confirmation of diagnosis with a tracheal diameter of more than $30 \mathrm{~mm}, 2 \mathrm{~cm}$ above the aortic arch and right bronchial diameter more than $20 \mathrm{~mm}$ as well as left bronchial diameter more than $18 \mathrm{~mm} .{ }^{34}$ Bronchoscopy reveals proximal airway dilation, tracheal and bronchial diverticula, and retained secretion. An obstructive pattern of pulmonary function test can supplement the diagnosis. Asymptomatic patients require no specific treatments, apart from cessation of smoking and limiting occupational pollutant or irritant exposure. The respiratory rehabilitation like chest physiotherapy for clearing secretion and antibiotics are the mainstay of treatment in cases with infectious exacerbation. ${ }^{5}$ Airway stenting and tracheobronchoplasty have also been suggested for significant airway collapse with variable result. ${ }^{5}$

Contributors AC, PS and RK were involved in the clinical care, literature review, diagnosis and management of the case. AC had prepared the manuscript, and PS, $A B$ and RK had done the final revision of the manuscript to be submitted. $A B$ had provided the radiological details of the patient.

Funding The authors have not declared a specific grant for this research from any funding agency in the public, commercial or not-for-profit sectors.

Competing interests None declared.

Patient consent for publication Obtained.

Provenance and peer review Not commissioned; externally peer reviewed.

\section{ORCID iDs}

Aswin Chandran http://orcid.org/0000-0003-3829-9872

Prem Sagar http://orcid.org/0000-0001-5590-9279

\section{REFERENCES}

1 Woodring JH, Howard RS, Rehm SR. Congenital tracheobronchomegaly (MounierKuhn syndrome): a report of 10 cases and review of the literature. $J$ Thorac Imaging 1991;6:1-10.

2 Fortuna FP, Irion K, Wink C, et al. Mounier-Kuhn syndrome. J Bras Pneumol 2006;32:180-3.

3 Menon B, Aggarwal B, Iqbal A. Mounier-Kuhn syndrome: report of 8 cases of tracheobronchomegaly with associated complications. South Med J 2008;101:83-7.

4 Dunne MG, Reiner B. Ct features of tracheobronchomegaly. J Comput Assist Tomogr 1988;12:388-91.

5 Krustins E, Kravale Z, Buls A. Mounier-Kuhn syndrome or congenital tracheobronchomegaly: a literature review. Respir Med 2013;107:1822-8.

Copyright 2021 BMJ Publishing Group. All rights reserved. For permission to reuse any of this content visit

https://www.bmj.com/company/products-services/rights-and-licensing/permissions/

BMJ Case Report Fellows may re-use this article for personal use and teaching without any further permission.

Become a Fellow of BMJ Case Reports today and you can:

- Submit as many cases as you like

- Enjoy fast sympathetic peer review and rapid publication of accepted articles

- Access all the published articles

- Re-use any of the published material for personal use and teaching without further permission

Customer Service

If you have any further queries about your subscription, please contact our customer services team on +44 (0) 2071111105 or via email at support@bmj.com.

Visit casereports.bmj.com for more articles like this and to become a Fellow 